\title{
Environmental Synergisms and Extinctions of Tropical Species
}

\author{
WILLIAM F. LAURANCE*† AND DIANA C. USECHE* \\ *Smithsonian Tropical Research Institute, Apartado 0843-03092, Balboa, Ancón, Panama \\ †School of Marine and Tropical Biology, James Cook University, Cairns, Queensland 4870, Australia, email bill.laurance@jcu.edu.au
}

\begin{abstract}
Environmental synergisms may pose the greatest threat to tropical biodiversity. Using recently updated data sets from the International Union for Conservation of Nature (IUCN) Red List, we evaluated the incidence of perceived threats to all known mammal, bird, and amphibian species in tropical forests. Vulnerable, endangered, and extinct species were collectively far more likely to be imperiled by combinations of threats than expected by chance. Among 45 possible pairwise combinations of 10 different threats, 69\%, 93\%, and $71 \%$ were significantly more frequent than expected for threatened mammals, birds, and amphibians, respectively, even with a stringent Bonferroni-corrected probability value $(\mathrm{p}=0.003)$. Based on this analysis, we identified five key environmental synergisms in the tropics and speculate on the existence of others. The most important involve interactions between habitat loss or alteration (from agriculture, urban sprawl, infrastructure, or logging) and other anthropogenic disturbances such as bunting, fire, exotic-species invasions, or pollution. Climatic change and emerging patbogens also can interact with other threats. We assert that environmental synergisms are more likely the norm than the exception for threatened species and ecosystems, can vary markedly in nature among geographic regions and taxa, and may be exceedingly difficult to predict in terms of their ultimate impacts. The perils posed by environmental synergisms bighlight the need for a precautionary approach to tropical biodiversity conservation.
\end{abstract}

Keywords: climatic change, endangered species, environmental synergisms, extinction, fire, habitat fragmentation, hunting, IUCN Red Data Book, logging, species invasions, tropical forests

Sinergismos Ambientales y Extinciones de Especies Tropicales

Resumen. Los sinergismos ambientales pueden constituir la mayor amenaza para la biodiversidad tropical. Utilizando conjuntos de datos de la Lista Roja de la Unión Internacional para la Conservación de la Naturaleza (IUCN) actualizados recientemente, evaluamos la incidencia de amenazas percibidas para todas las especies conocidas de mamíferos, aves y anfibios de bosques tropicales. Las especies vulnerables, en peligro y extintas colectivamente fueron más afectadas por combinaciones de amenazas que lo esperado al azar. Entre las 45 combinaciones pareadas posibles de 10 amenazas diferentes, 69\%, 83\% y $71 \%$ fueron significativamente más frecuentes que lo esperado para especies amenazadas de mamíferos, aves y anfibios, respectivamente, aun con un valor de probabilidad con corrección Bonferoni $(\mathrm{p}=0.003)$. Con base en este análisis, identificamos cinco sinergismos ambientales clave en los trópicos y especulamos con la existencia de otros. Las más importantes involucran interacciones entre la pérdida o alteración de bábitat (por agricultura, expansión urbana, infraestructura o explotación de madera) y otras perturbaciones antropogénicas como la cacería, el fuego, invasiones de especies exóticas o contaminación. El cambio climático y los patógenos emergentes también pueden interactuar con otras amenazas. Afirmamos que los sinergismos ambientales son más la norma que la excepción para especies y ecosistemas amenazados, que pueden variar notablemente entre regiones geográficas y taxa, y que pueden ser extremadamente difíciles de predecir en términos de sus impactos finales. Los peligros que representan los sinergismos ambientales resaltan la necesidad de un enfoque precautorio para la conservación de la biodiversidad tropical.

Palabras Clave: bosques tropicales, cacería, cambio climático, especies en peligro, explotación de madera, extinción, fragmentación de hábitat, fuego, invasiones de especies, Libro Rojo IUCN, sinergismos ambientales 


\section{Introduction}

We doubt that there is a landscape anywhere in the tropics that is affected by only one environmental change. Consider, for instance, a fragmented forest in the Amazon. In all likelihood the forest and wildlife communities in this landscape are not merely reduced and isolated, but they are also subject to an array of other environmental changes, such as hunting (Cullen et al. 2000; Peres 2001), selective logging (Mikalski \& Peres 2005), destructive surface fires (Gascon et al. 2000; Cochrane \& Laurance 2002), and local climatic alterations (Laurance 2004). Such changes are facilitated by and considerably exacerbate the ecological impacts of habitat fragmentation.

As a second example, envision a far more pristine ecosystem, a protected cloud forest in the Wet Tropics World Heritage Area in north Queensland, Australia. Although it might seem nearly immune to human activities, many of the stream-dwelling amphibians in this system have already been driven to local or global extinction by an exotic pathogen (Laurance et al. 1996; Berger et al. 1998), possibly in concert with one or more environmental stressors (Pounds et al. 2006; Alford et al. 2007). The forest and its species are also potentially suffering because of airborne inputs of pollutants and pesticides (Davidson et al. 2002; Taylor et al. 2003), the presence of invasive animals and plants (Laurance \& Harrington 1997; Humphries \& Stanton 1992), disturbances from tourists (Griffiths \& van Shaik 1993; Reed \& Merenlender 2008), rising temperatures (Williams et al. 2003; Hilbert et al. 2004; Laurance 2008a), changing atmospheric composition (Kanowski 2001), and increasing cyclone disturbances (Walsh \& Ryan 2000; Turton 2008) associated with global-scale climatic change.

These examples suggest that virtually all ecosystemseven those one might consider largely pristine-are in fact affected by suites of environmental changes. In many cases, we believe, these changes have the potential to operate synergistically or in concert, possibly magnifying their individual effects. Such synergisms could have crucial implications for biodiversity survival, given the panoply of different environmental changes occurring in an increasingly diminished and altered tropical world.

To assess the potential for tropical species to be influenced by such synergisms, we used the International Union for Conservation of Nature (IUCN) Red List (cf. Schipper et al. 2008) to examine the incidence of multiple threats perceived to be affecting extinction-prone and extinct species. We identified five synergisms that have particularly large potential to alter tropical ecosystems and increase species extinctions and other poorly understood synergisms that might become increasingly important in the future.

\section{Background on Synergisms}

Synergisms among environmental changes are of growing interest in the field of conservation science. Much prior research has focused on the potential for chemical pollutants to have synergistic impacts on human or wildlife health. Some endocrine-disrupting chemicals (ECDs), for example, interact synergistically even at low concentrations, leading to far greater effects than any one ECD operating alone (Porter et al. 1999; Zala \& Penn 2004). Other researchers have assessed the synergistic impacts of pathogens and environmental stressors, such as UV-B radiation (Kiesecker \& Blaustein 1995), pesticides (Kiesecker 2002), and climate change (Pounds et al. 2006; Traill et al. 2009), on wildlife survival.

Myers $(1986,1996)$ was among the first to emphasize that environmental synergisms might potentially drive large-scale species extinctions. This was followed by a special section in Conservation Biology on synergistic effects in fragmented landscapes (Laurance \& Cochrane 2001), including studies of how impacts of fragmentation can be exacerbated by livestock grazing and weed invasions (Hobbs 2001), hunting (Peres 2001), drought (Laurance \& Williamson 2001), and air pollution (Weathers et al. 2001). Even when temporary, such ancillary disturbances can greatly elevate the impacts of habitat loss and fragmentation on species survival (Casagrandi \& Gatto 2002).

In a world being altered in many different ways simultaneously, the potential variety of environmental synergisms is clearly enormous. An increasingly prevalent view is that global extinctions of species are often caused not by single threats, or even by a series of distinct threats operating independently in time and space, but by alarming synergisms among multiple, interacting threats (Pimm 1996; Brook et al. 2008).

\section{Evidence for Tropical Synergisms}

To assess the potential for synergisms to imperil tropical biodiversity, we used recently updated (circa 2008), relational databases compiled for the IUCN Red List of Endangered Animals (www.iucnredlist.org) for mammals, birds, and amphibians. These databases, combining knowledge from thousands of experts, provide the best available information on the status and known threats to extant and recently extant species (cf. Schipper et al. 2008; Vié et al. 2008). The data sets for mammals, birds, and amphibians are considered complete or nearly so for all known species (J. Schipper, personal communication)

We confined our analyses to species found in tropical and subtropical forests-including all subformations of these forest types-and included species categorized 
Table 1. Percentages of known tropical forest mammals, birds, and amphibians imperiled by 10 categories of anthropogenic threat, according to the IUCN Red List*.

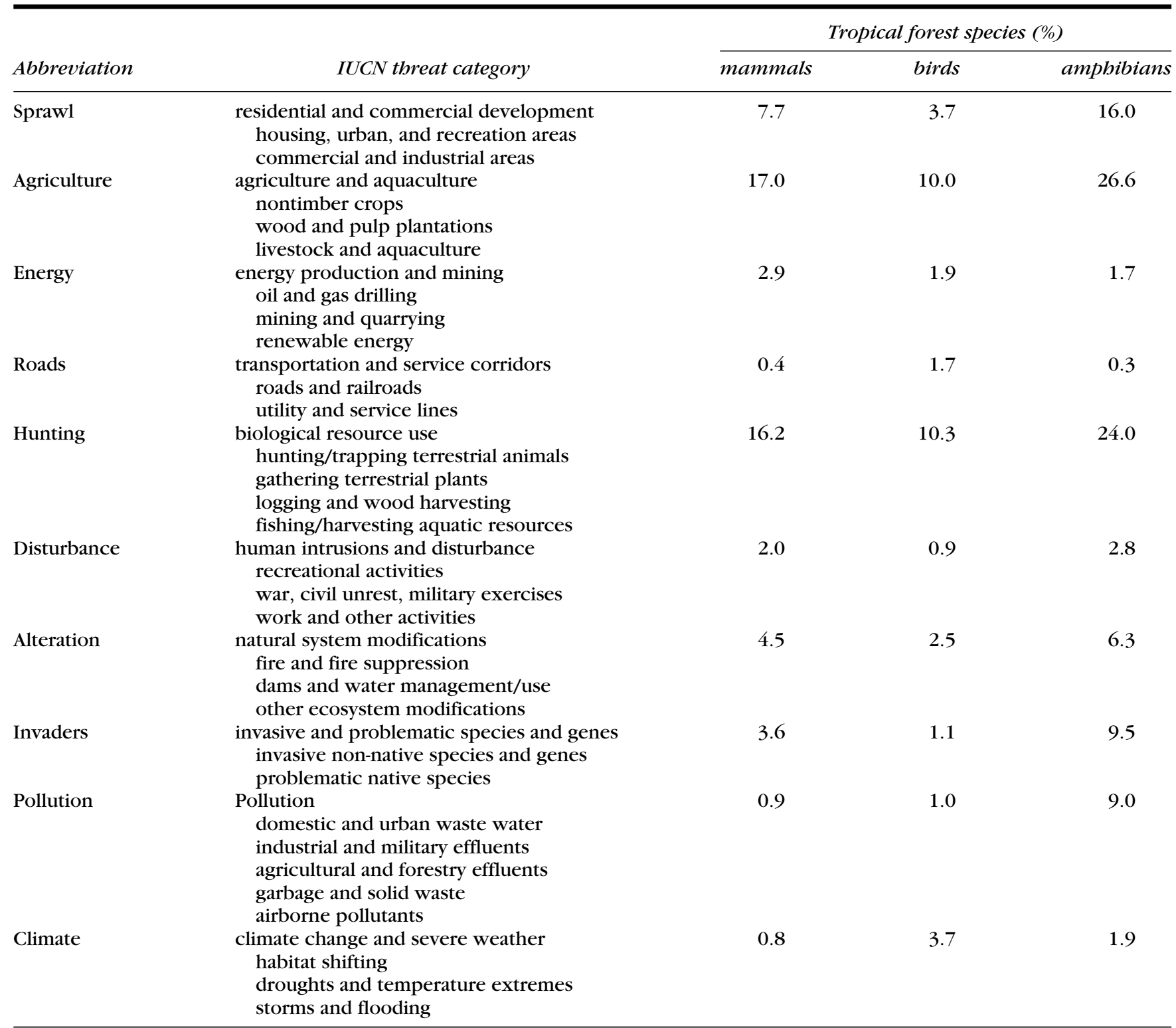

*Listed as vulnerable, endangered, critically endangered, extinct in the wild, or extinct (IUCN, International Union for Conservation of Nature).

as vulnerable, endangered, critically endangered, extinct in the wild, and extinct, which we collectively refer to as imperiled. Analyses run without vulnerable species revealed very similar patterns, so we report only the former here. We included in our analyses 3296 tropical mammal species, of which $21.7 \%$ (714) were imperiled; 7128 tropical bird species, of which $12.7 \%$ (907) were imperiled; and 4728 tropical amphibian species, of which $32.0 \%$ (1512) were imperiled.

For each faunal group, we determined the percentage of all tropical forest species suffering from 10 general categories of anthopogenic threat, using a standardized classification of threats devised by Salafsky et al. (2008).
These threats are broad in scope and their titles are abbreviated here (Table 1). For all three groups, agriculture and hunting were considered the top two threats, but patterns differed for other threats. Climate change was a relatively important threat to birds, whereas invasive species, pollution, and ecosystem alteration (e.g., dams, river channelization) threatened many amphibians.

We then determined the incidence of pairwise combinations of threats to each faunal group. For each of 45 possible pairs of threats (e.g., agriculture + hunting), we used the IUCN database to determine the number of imperiled species suffering from both threats simultaneously. We compared this observed value with an 
expected number of imperiled species, which we derived by multiplying the total number of species by the proportions affected by each individual threat. (For instance, if we had 1000 mammal species and $20 \%$ suffered from agriculture and $10 \%$ from hunting, then the number expected to suffer from both was $1000 \times 0.2 \times 0.1=$ 20).

For each pair of threats, we contrasted observed and expected values by (1) calculating the variance of the binomial distribution (as $N[p q(1-p q)]$, where $N$ is the total number of tropical forest species and $p$ and $q$ are the respective proportions affected by each threat); (2) assuming the normal approximation to the binomial distribution for large sample sizes (because $N>3000$ species in all cases); (3) taking the square-root of the variance to yield the standard deviation (SD); and (4) using a twotailed $Z$ test to contrast the observed and expected values $[Z=($ observed - expected $) / S D]$. We used a Bonferronicorrected alpha value $(p=0.003)$ to reduce the likelihood of type II statistical errors (Chandler 1995) when evaluating the 45 pairs of threats.

Our results suggested that imperiled tropical species are far more likely to suffer from combinations of threats than expected by chance. Among 45 possible threat combinations, $69 \%, 93 \%$, and $71 \%$ affected significantly $(p \leq$ 0.003 ) more species than expected for imperiled mammals, birds, and amphibians, respectively, even with the stringent Bonferroni correction. Thus, threats were far from randomly distributed across tropical forest species, with imperiled species often suffering from particular "clumps" of threats, rather than just a single threat.

The most important threat combinations were similar across taxa (Fig. 1). For mammals, birds, and amphibians, the top three combinations were identical; the most important was agriculture and hunting, which was followed by agriculture and rural or urban sprawl, and then sprawl and hunting. Thus, habitat loss or modification in concert with overharvesting was the most pervasive type of threat combination overall. Despite these similarities, the percentage of species affected by each threat combination varied substantially among groups, with relatively many amphibians and relatively few birds being imperiled overall.

Lesser threat combinations were more variable among taxa (Fig. 1). For instance, birds appeared particularly vulnerable to synergisms involving climate change and hunting. Amphibians suffered from many threat combinations, several of which involve pollution or invading species (introduced predators, competitors, and emerging pathogens). Many mammals suffered from habitat alteration, such as that caused by altered fire regimes.

These patterns do not demonstrate definitively that synergisms are driving the decline of tropical forest species, but they suggest that particular combinations of threats are far more common among imperiled species than expected by chance.

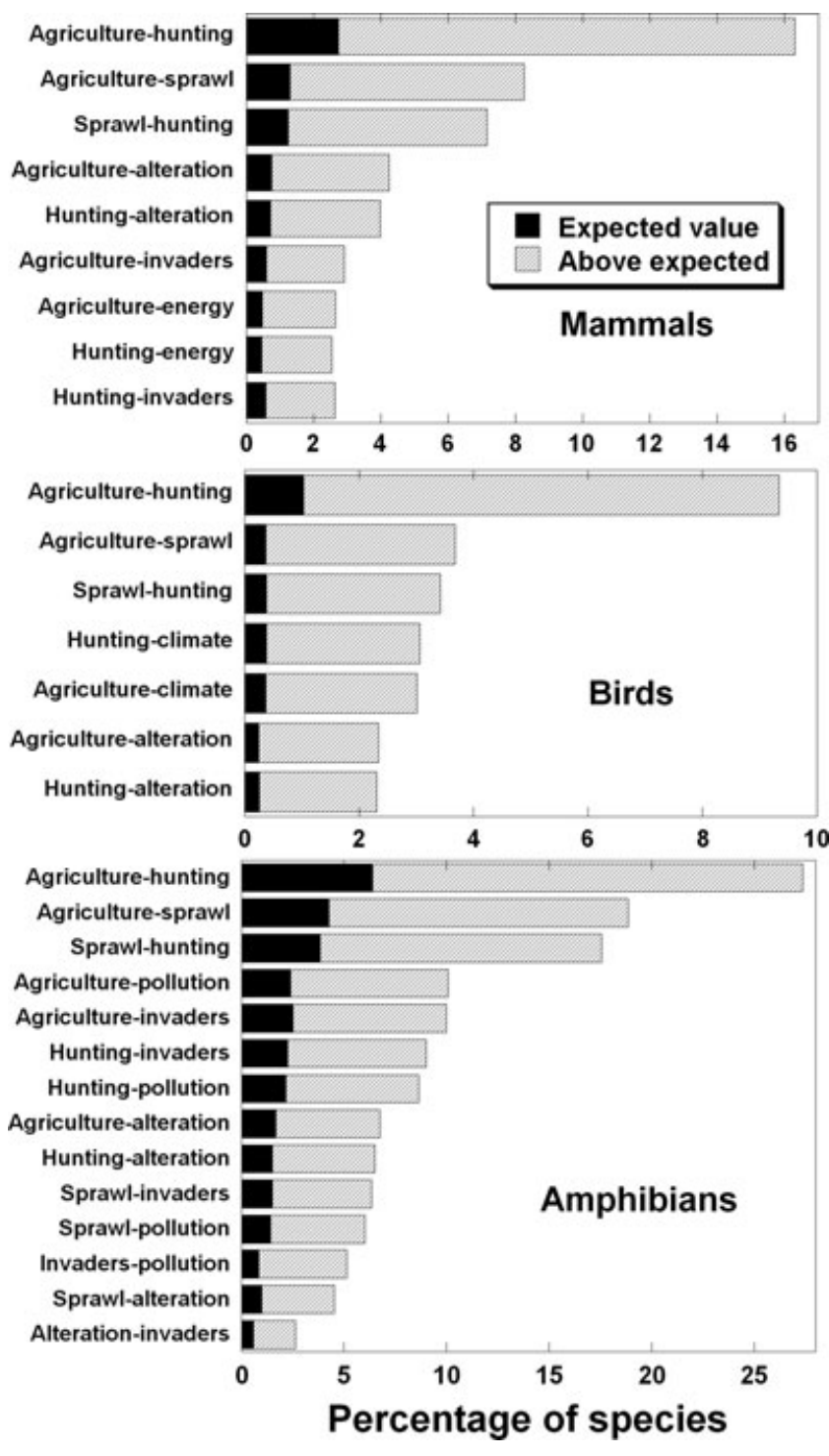

Figure 1. Expected and observed (expected + above expected) frequencies of combinations of environmental threats to imperiled mammal, bird, and amphibian species based on the International Union for Conservation of Nature (IUCN) Red List. Only threat combinations affecting $>2 \%$ of tropical forest species are shown.

\section{Habitat Alteration and Hunting}

Agriculture and hunting are not only the largest individual threats to tropical vertebrates (Table 1), but they also simultaneously affect a far higher proportion of imperiled species than expected by chance (Fig. 1). One key example of this is the strong synergism between hunting and forest loss and fragmentation (Chiarello 2000; Cullen et al. 2000; Peres 2001). Species in fragmented forests often have small, isolated populations and are more accessible to hunters than those in continuous 
forest. Numerous hunted species, such as tapirs, peccaries, larger primates, and cracid birds, can be depleted or extirpated in fragmented landscapes (Cullen et al. 2000; Peres 2001). For wide-ranging species such as predators and large mammals, persecution or hunting in the matrix habitats surrounding fragments can be a critical driver of local extinction (Woodroffe \& Ginsberg 1998). The loss of large and dominating predators can then disrupt the trophic structure and biodiversity of fragmented forests (Terborgh et al. 2001).

A related synergism involves hunting and selective logging, one of the most ubiquitous land uses in the tropics (Asner et al. 2009 [this issue]). When forests are logged but unhunted, even disturbance-sensitive species frequently persist, albeit in reduced abundances (Johns 1997). Wildlife populations often plummet in hunted forests, however, because the labyrinths of roads created by logging greatly increase access to forests for hunters and poachers and the loggers themselves often hunt avidly (Robinson et al. 1999). A single large logging camp in Sarawak, for example, was estimated to consume $33,000 \mathrm{~kg}$ of bushmeat annually (Bennett \& Gumal 2001).

Across the tropics, the impact of the logging-hunting synergism is growing. Loggers are now penetrating into the last surviving forest frontiers, such as the Amazon (Asner et al. 2005, 2009), Borneo (Curran et al. 1999), New Guinea (Shearman et al. 2008), and the Congo Basin (Laporte et al. 2007). Unexploited core areas of forest, which are crucial for the long-term persistence of vulnerable populations, are rapidly shrinking (Wilkie et al. 2000; Laurance et al. 2001; Blake et al. 2008). In addition, the efficiency of hunters has increased because shotguns and cable snares have replaced traditional crossbows, spears, and nets (Noss 1998), which allows many species to be exploited. For example, among 57 mammal, bird, and reptile species hunted in the Congo Basin, $60 \%$ are being harvested unsustainably (Fa et al. 2002). Large-bodied

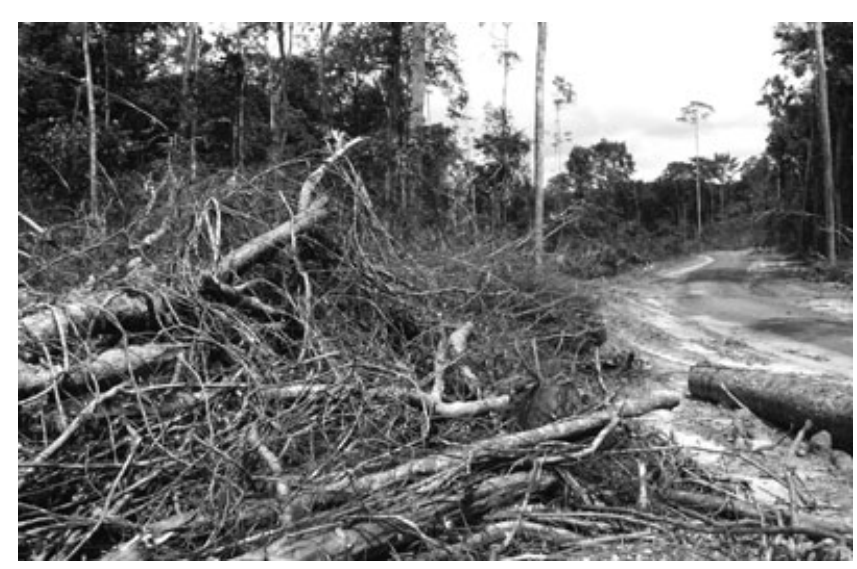

Figure 2. Example of fine, flammable fuel in selectively logged forest in central Africa (photo by W.F.L.). species and those with low reproductive rates are most imperiled (Robinson \& Bennett 2000).

\section{Logging and Fire}

Another key synergism in the tropics is an interaction between selective logging and fire (Holdsworth \& Uhl 1997; Nepstad et al. 1999; Siegert et al. 2001), and it falls under the hunting-alteration synergism, a major threat to tropical vertebrates (Fig. 1), because "hunting" under the IUCN classification incorporates logging and other forms of biological resource use (Table 1 ).

In the tropics large, intact expanses of forest rarely burn; major fires typically occur just once or a few times per millennium during megadroughts (Sanford et al. 1985; Meggers 1994). The natural fire dynamic is radically altered by logging, which greatly increases the amount of flammable litter and debris in the forest understory (Fig. 2). Furthermore, by removing from 10 to $80 \%$ of the canopy cover, logging allows sunlight and wind to penetrate into the understory, increasing forest heating and desiccation. In Brazilian Amazonia at least $76 \%$ of logged forest had canopy damage severe enough to render the forest vulnerable to droughts and fire (Asner et al. 2006). Finally, logging roads greatly increase physical accessibility to forests for colonists and slash-and-burn farmers, which leads to a large increase in ignition sources (Laurance 2001).

The initial fires in logged forests are mostly lowintensity surface burns that consume litter and debris in the forest understory. These can nonetheless cause heavy plant mortality because most rainforest plants lack fire adaptations such as thick bark to protect their delicate vascular tissues (Cochrane et al. 1999; Barlow et al. 2003). Once degraded by an initial burn, the forest becomes far more vulnerable to secondary fires because dead fuel accumulates in the understory while the thinned canopy increases forest drying. Secondary fires are more intense and destructive than the initial burn, typically releasing 10 times as much heat (Cochrane et al. 1999) and causing severe plant mortality, even among the largest trees (Barlow et al. 2003). Many disturbance-sensitive animal and plant species decline or disappear in burned forests (Cochrane \& Schulze 1999; Barlow \& Peres 2004).

\section{Fragmentation and Fire}

Another key threat in the major agriculture-alteration synergism (Fig. 1) is the interaction between forest fragmentation and fire (Cochrane \& Laurance 2002, 2009; Alencar et al. 2006). In the tropics forest fragments are often juxtaposed with frequently burned lands such as pastures or slash-and-burn farming plots. The fragments 
also have dry, fire-prone edges (Kapos 1989) and oftenheavy tree mortality near their margins from wind throw and desiccation stress (Laurance et al. 1998). The accumulation of wood debris and litter creates an abundance of fine, flammable fuel, and canopy damage increases forest desiccation (Nascimento \& Laurance 2004). Many forest fragments are also selectively logged, further increasing canopy damage and flammable litter (Cochrane \& Laurance 2002; Alencar et al. 2004).

Forest desiccation in fragmented landscapes can be increased by local and regional changes in climate. Evapotranspiration declines as forests are replaced by pastures or croplands, which reduces moisture inputs into the atmosphere (Jipp et al. 1998). This can diminish local cloud cover and evaporative cooling and thus elevate surface temperatures and lower relative humidity (Nobre et al. 1991). Rainfall may also decline, particularly during the crucial dry-season months when forests are most flammable, although the relationship between forest cover and rainfall is probably not linear (Baidya Roy \& Avissar 2002; Negri et al. 2004). Rainfall is further reduced by biomass burning because the atmosphere becomes hypersaturated with smoke aerosols that trap water molecules and warm the air via solar heating (Rosenfeld 1999; Koren et al. 2004). In tropical regions such as the Amazon and Southeast Asia, moisturetrapping smoke plumes from biomass fires can extend for thousands of kilometers (Fig. 3), which creates vast downwind rain shadows (Aragão et al. 2008).

The combination of changes affecting fragmented landscapes-increased desiccation, abundant flammable fuel, and many ignition sources-can drastically elevate fire incidence (Fig. 4). Amazonian forest remnants affected by recurring surface fires are sometimes destroyed

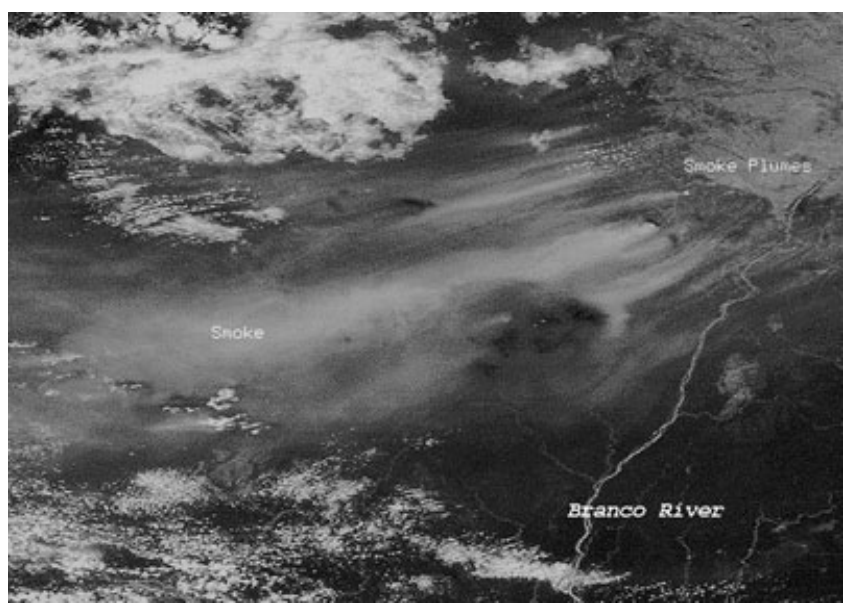

Figure 3. Heavy smoke in northern Amazonia suppresses cloud cover and rainfall, as illustrated by this thermal-satellite scene (image courtesy of National Aeronautic and Space Administration, circa 1998).

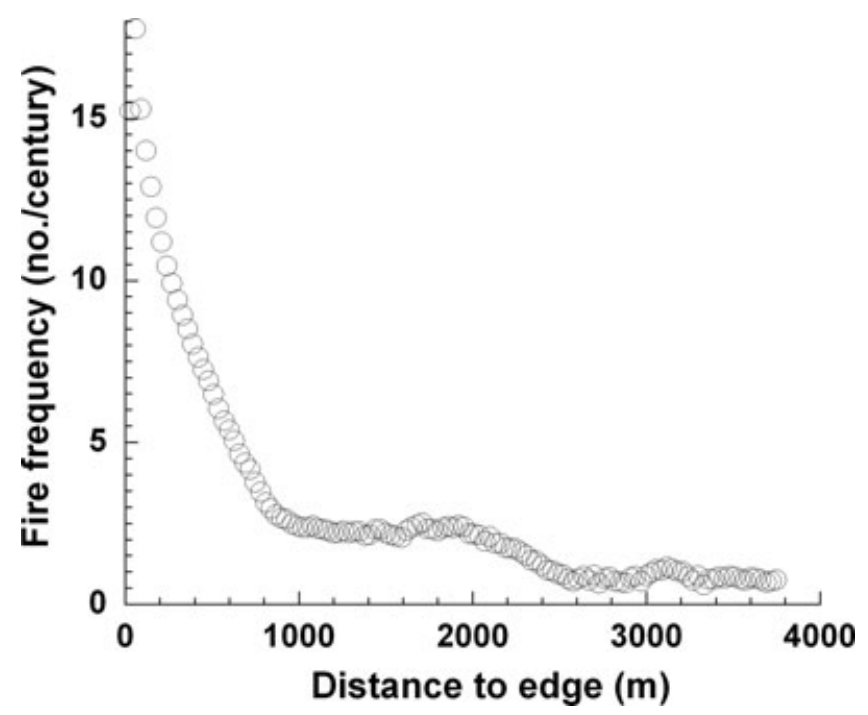

Figure 4. Incidence of surface fires (as revealed by 14 years of satellite imagery) near forest edges in eastern Amazonia (adapted from Cochrane \& Laurance 2002).

completely in just a few years (Cochrane \& Laurance 2002). The fragmentation-fire synergism is especially serious in regions that experience strong dry seasons or periodic droughts and on soils with limited waterholding capacity (Alencar et al. 2006). In Brazilian Amazonia roughly 45 million ha of forest-an area twice the size of Great Britain-is vulnerable to edge-related fires (Cochrane 2001). Hence, the fire-fragmentation synergism promotes rapid habitat loss and disruption at the expense of many disturbance-sensitive and forest-interior species (Cochrane \& Schulze 1999; Barlow et al. 2003; Barlow \& Peres 2004).

\section{Climate Change and Habitat Alteration}

Although a major threat combination at present only for birds, synergisms between habitat disruption and climate change (agriculture-climate synergism; Fig. 1) could emerge as an important hazard to tropical biodiversity. Efforts to predict such interactions, however, are plagued by considerable uncertainty about the future impacts of climatic change on tropical ecosystems (Lewis et al. 2004; Wright 2005). We have alarmingly little confidence, for example, in how future global warming will affect tropical precipitation (Vera et al. 2006) (Fig. 5). This is a major concern because precipitation, far more than temperature, governs the distribution of tropical vegetation and its vulnerability to fire. Other key uncertainties concern the effects of rising atmospheric $\mathrm{CO}_{2}$ and temperature on tropical forest dynamics, species composition, and carbon storage (Phillips et al. 1998; Clark et al. 

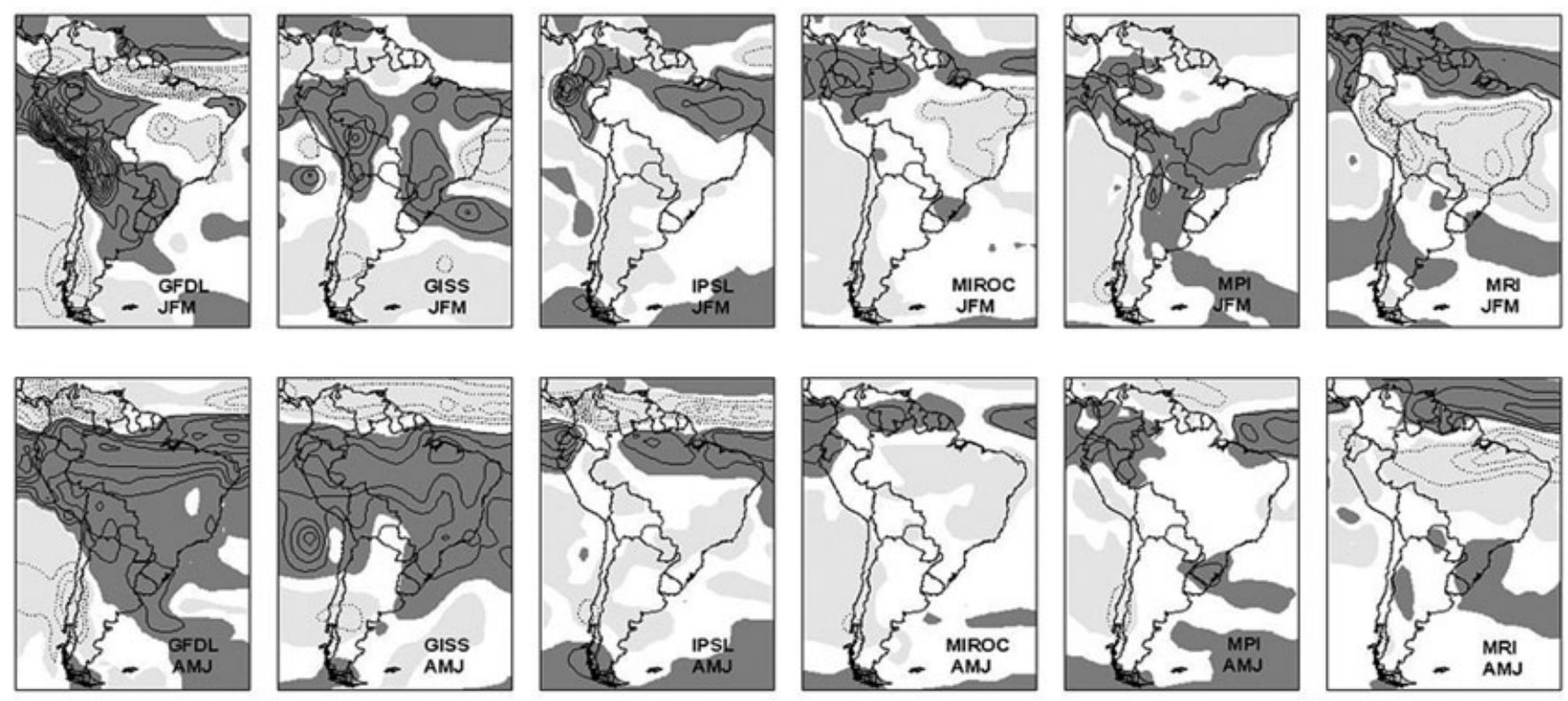

Figure 5. Projected changes in future Soutb American precipitation in the austral summer (top row: JFM, January, February, March) and autumn (bottom row: AMJ, April, May, June) on the basis of six different global-circulation models (GDFS, GISS, etc). The models were run under identical conditions (720 ppm of atmospheric $\mathrm{CO}_{2}$ ) for the period 2070-2099, but bad different climate algoritbms to project future precipitation. Dark gray areas are predicted to become markedly wetter and light gray areas markedly drier relative to the period 1970-1999. Contour lines indicate precipitation changes of $1 \mathrm{~mm} /$ day (increasing rainfall is shown by solid contours and declining rainfall by dotted contours). The wide variation among these state-of-the-art models illustrates bow little confidence there is in bow tropical precipitation will be affected by global warming. Adapted from Vera et al. (2006).

2003; Laurance et al. 2004; Feeley et al. 2007; Chave et al. 2008).

We do, nonetheless, have a somewhat better idea of how global warming will affect tropical biota (Wright et al. 2009 [this issue]). Mountainous areas in the tropics support concentrations of locally endemic species that are often physiologically specialized for cool, upland conditions (Fjeldså \& Lovett 1997; Navas 1997; Rahbek 1997). Unlike species at higher latitudes, tropical organisms tend to be thermal specialists because they experience relatively little variation in temperature throughout the year (Janzen 1967; Deutsch et al. 2008; Wright et al. 2009).

As temperatures continue to rise in the future, the geographic ranges of higher elevation species are likely to shrink and fragment (Williams et al. 2003; Hilbert et al. 2004; Deutsch et al. 2008). Mid- and low-elevation species are expected to migrate upward, at least in areas near elevational gradients (Colwell et al. 2008; Wright et al. 2009). Rising temperatures will also elevate the cloud base, which provides key inputs of mist and cloud water for many montane forests (Cavalier et al. 1996). Moisture inputs could be further diminished as regional evapotranspiration declines, both from increasing deforestation and because plants might respire less as atmospheric $\mathrm{CO}_{2}$ rises (Lewis et al. 2004).
Collectively, such changes could cause serious alterations of upland climates that could imperil many tropical species (Williams et al. 2003; Thomas et al. 2004; Malcolm et al. 2006; Williams et al. 2007). The impacts of such changes will be aggravated by generally intense habitat alteration at higher elevations (Geist \& Lambin 2001), although forest regeneration in some upland areas (Asner et al. 2009; Rudel et al. 2009 [this issue]) could partially counter this trend. Thus, in at least some upland areas, tropical species are likely to be trapped between global warming and habitat disruption. Rising temperatures will force them into higher elevations, but the migration corridors and upland habitats they require for migration and survival will often be missing. For mountaintop endemics, the likelihood of global extinction could rise sharply (Laurance 2009).

\section{Pathogens and Stressors}

Pathogens probably pose a far greater threat to tropical biota than is commonly appreciated. A key factor is escalating "pathogen pollution," the transportation of diseasecausing organisms worldwide via international trade and travel. Consequently, many species are being exposed 
to invading or emerging pathogens for which they have little if any natural immunity (Daszak et al. 2000). Environmental stressors, such as habitat degradation, UV radiation, and pollutants, can also elevate susceptibility to pathogens (Lafferty \& Holt 2003), and global warming will increase the geographic range and virulence of many disease-causing organisms and vectors (Epstein 2001; Harvell et al. 2002; Pounds et al. 2006; Traill et al. 2009). Synergisms between pathogens and stressors seem particularly likely for imperiled amphibians (Fig. 1), for which invaders (including emerging pathogens and other invasive species) often occur in combination with other anthropogenic threats.

Pathogens are most likely to drive species to global extinction when the host population is small and the pathogen has a biotic or abiotic reservoir in nature (de Castro \& Bolker 2005). Even when the pathogen does not fully exterminate a species, population collapse and loss of genetic variability can be so severe that other agents of decline, such as habitat loss or overexploitation, can then drive it to extinction (de Castro \& Bolker 2005; Gerber et al. 2005). Wildlife diseases are difficult to study, and current data on species endangerment almost certainly underestimate the role of disease in species extinctions (Smith et al. 2006).

Even with limited available data, it is apparent that pathogens are already having serious impacts on tropical biodiversity. The rapid disappearance of many streamdwelling amphibians from chytridiomycosis, the collapse of African ungulate populations from rinderpest, the global extinctions of many Hawaiian birds from avian malaria and pox, the permanent loss of Partula tree snails, and the virtual extirpation of Diadema sea urchins are all examples of tropical extinctions or near extinctions driven at least in part by pathogenic disease (Daszak et al. 2000; de Castro \& Bolker 2005). In yet other cases, such as central-African apes (Walsh et al. 2003) and some declining amphibians (Daszak et al. 2000), pathogens have caused drastic population declines but not extinctions per se. As the numbers of emerging pathogens and environmental stressors multiply, disease-related extinctions will almost certainly increase.

\section{Conclusions}

The five synergisms highlighted above pose important threats to tropical biodiversity, but this list is far from comprehensive. For example, forest disturbance can greatly increase invasions by foreign species (Didham et al. 2007). Some invaders, including fire-promoting weeds, noxious insects (e.g., fire ants), and the generalist pathogen Pbytophtbora, which causes forest dieback, can seriously alter forest biodiversity and functioning (Simberloff \& Von Holle 1999; O’Dowd et al. 2003). In addition to such environmental synergisms, important ecological linkages can develop between tropical forests and nearby marine ecosystems. In central Africa, for instance, overexploitation of marine fisheries by European commercial trawlers is forcing coastal communities to poach more intensively in national parks, which is reducing the abundances of 40 mammal species (Brashares et al. 2004). In the same region, industrial logging is indirectly harming endangered sea turtles; thousands of lost and abandoned logs from timber operations are floating ashore onto beaches where they impede or kill nesting turtles (Laurance et al. 2008). The closer one looks, the more synergies and ecological linkages one will discover.

Many ecosystems suffer from multiple ecological synergisms. Biota in fragmented landscapes, for instance, are not merely reduced and isolated, but also may be subject to intensive hunting, selective logging, destructive fires, altered climatic conditions and hydrology, species invasions, and air pollution, among other phenomena (Woodroffe \& Ginsberg 1998; Curran et al. 1999; Laurance \& Cochrane 2001; Peres 2001; Weathers et al. 2001). Teasing apart the ecological impacts of such manifold, interacting perturbations might be exceedingly difficult, but it does not alter the reality that they are likely to occur in most human-altered ecosystems.

The nature and importance of synergisms are likely to vary geographically (Sala et al. 2000) and among taxa (e.g., Fig. 1). In the Amazon, for instance, interactions among logging, forest fragmentation, surface fires, hunting, and regional climate change might all be important. In higher elevation ecosystems, global warming, habitat loss, and exotic pathogens or competitors could have the largest effects. Invasive species and habitat disruption may have the greatest impacts on oceanic islands. The suite of threats affecting coastal areas may well differ from those in inland regions, whereas environmental perils in, say, southern Asia will undoubtedly vary from those in West Africa. Even nearby landscapes can experience surprisingly different threats and dynamics (Laurance et al. 2007). For such reasons it is difficult to generalize about the importance of particular environmental synergisms, although certain interactions, such as the five examples we highlight above, are likely to be of broad importance.

In our view the complexities and uncertainties inherent in environmental synergisms and their potential to cause severe and unanticipated impacts create a strong need for a precautionary approach to biodiversity conservation (Howard 2002; Laurance 2008b). Those who argue that the threat of habitat conversion to tropical biodiversity has been overstated (Wright \& Muller-Landau 2006) might be correct, but they might easily be wrong. In an era in which tropical forests are falling at the rate of 50 football fields a minute and in which rampant habitat disruption is potentially being exacerbated by other, 
manifold anthropogenic changes, we prefer to err on the side of caution. The consequences of misplaced optimism are simply too grave to contemplate.

\section{Acknowledgments}

We thank J. Wright, R. Ewers, R. Butler, and two anonymous referees for many helpful comments, C. Vera for permission to use Fig. 5, and the Smithsonian Institution, Science Committee of the Smithsonian National Board, and Frank Levinson Family Foundation for support.

\section{Literature Cited}

Alencar, A., D. Nepstad, and M. Vera Diaz. 2006. Forest understory fire in the Brazilian Amazon in ENSO and non-ENSO years: area burned and committed carbon emissions. Earth Interactions 10:1-17.

Alencar, A., L. Solórzano, and D. Nepstad. 2004. Modeling forest understory fires in an eastern Amazonian landscape. Ecological Applications 14:S139-S149.

Alford, R. A., K. Bradfield, and S. Richards. 2007. Global warming and amphibian losses. Nature 447:E3-E4.

Aragão, L., Y. Malhi, N. Barbier, A. Lima, Y. Shimabukuro, L. Anderson, and S. Saatchi. 2008. Interactions between rainfall, deforestation and fires during recent years in the Brazilian Amazonia. Philosophical Transactions of the Royal Society B 363:1779-1785.

Asner, G., D. Knapp, E. Broadbent, P. Oliveira, M. Keller, and J. Silva. 2005. Selective logging in the Brazilian Amazon. Science 310:480482.

Asner, G., E. Broadbent, P. Oliveira, M. Keller, D. Knapp, and J. Silva. 2006. Condition and fate of logged forests in the Brazilian Amazon. Proceedings of the National Academy of Sciences USA 103:1294712950.

Baidya Roy, S., and R. Avissar. 2002. Impact of land use/land cover change on regional hydrometeorology in the Amazon. Journal of Geophysical Research 107:DOI:10.1029/2000JD00266.

Barlow, J., and C. Peres. 2004. Ecological responses to El Niño-induced surface fires in central Amazonia: management implications for flammable tropical forests. Philosophical Transactions of the Royal Society B 59:367-380.

Barlow, J., C. Peres, B. Lagan, and T. Haugaasen. 2003. Large tree mortality and the decline of forest biomass following Amazonian wildfires. Ecology Letters 6:6-8.

Bennett, E. L., and M. Gumal. 2001. The interrelationships of commercial logging, hunting, and wildlife in Sarawak: recommendations for forest management. Pages 359-374 in R. Fimbel, A. Grajal, and J. G. Robinson, editors. The cutting edge: conserving wildlife in logged tropical forests. Columbia University Press, New York.

Berger, L., et al. 1998. Chytridiomycosis causes amphibian mortality associated with population declines in the rain forests of Australia and Central America. Proceedings of the National Academy of Sciences USA 95:9031-9036.

Blake, S., S. Deem, S. Strindberg, F. Maisel, L. Momonts, I.-B. Isia, I. Douglas-Hamilton, W. Karesh, and M. Kock. 2008. Roadless wilderness area determined forest elephant movements in the Congo Basin. Public Library of Science ONE DOI: 10.1371/journal.pone.0003546.

Brashares, J., P. Arcese, M. Sam, P. Coppolillo, A. Sinclair, and A. Balmford. 2004. Bushmeat hunting, wildlife declines, and fish supply in west Africa. Science 306:1180-1183.

Brook, B., N. Sodhi, and C. Bradshaw. 2008. Synergisms among extinction drivers under global change. Trends in Ecology \& Evolution 23:453-460.
Casagrandi, R., and M. Gatto. 2002. Habitat destruction, environmental catastrophes, and metapopulation extinction. Theoretical Population Biology 61:127-140.

Cavalier, J., D. Solis, and M. Jaramillo. 1996. Fog interception in montane forests across the Central Cordillera of Panama. Journal of Tropical Ecology 12:357-369.

Chandler, C. 1995. Practical considerations in the use of simultaneous inference for multiple tests. Animal Behaviour 49:524-527.

Chave, J., et al. 2008. Assessing evidence for a pervasive alteration in tropical tree communities. Public Library of Science Biology DOI:10.1371/journal.pbio.0060045.

Chiarello, A. 2000. Density and population size of mammals in remnants of Brazilian Atlantic forest. Conservation Biology 14:1649-1657.

Clark, D. A., S. Piper, C, Keeling, and D. B. Clark. 2003. Tropical rain forest tree growth and atmospheric carbon dynamics linked to interannual temperature variation during 1984-2000. Proceedings of the National Academy of Sciences USA 100:5852-5857.

Cochrane, M. 2001. In the line of fire: understanding the dynamics of tropical forest fires. Environment 43:28-38.

Cochrane, M., and M. Schulze. 1999. Fire as a recurrent event in tropical forests of the eastern Amazon: effects on forest structure, biomass, and species composition. Biotropica 31:2-16.

Cochrane, M., and W. F. Laurance. 2002. Fire as a large-scale edge effect in Amazonian forests. Journal of Tropical Ecology 18:311325.

Cochrane, M., and W. F. Laurance. 2009. Synergisms among fire, land use, and climate change in the Amazon. Ambio 37:522-527.

Cochrane, M., A. Alencar, M. Schulze, C. Souza, D. Nepstad, P. Lefebvre, and E. Davidson. 1999. Positive feedbacks in the fire dynamic of closed canopy tropical forests. Science 284:1837-1841.

Colwell, R. K., G. Brehm, C. Cardelus, A. Gilman, and J. Longino. 2008. Global warming, elevational range shifts, and lowland biotic attrition in the wet tropics. Science 322:258-261.

Cullen, L., R. E. Bodmer, and C. Valladares-Pádua. 2000. Effects of hunting in habitat fragments of the Atlantic forests, Brazil. Biological Conservation 95:49-56.

Curran, L., I. Caniago, G. Paoli, D. Astianti, M. Kusneti, M. Leighton, C. Nirarita, and H. Haeruman. 1999. Impact of El Niño and logging on canopy tree recruitment in Borneo. Science 286:2184-2188.

Daszak, P., A. Cunningham, and A. Hyatt. 2000. Emerging infectious diseases of wildlife - threats to biodiversity and human health. Science 287:443-449.

Davidson, C., H. Shaffer, and M. Jennings. 2002. Spatial tests of the pesticide drift, habitat destruction, UV-B, and climate-change hypotheses for California amphibian declines. Conservation Biology 16:1588-1601.

de Castro, F., and B. Bolker. 2005. Mechanisms of disease-induced extinction. Ecology Letters 8:117-126.

Deutsch, C., J. Tewksbury, R. Huey, K. Sheldon, C. Ghalambour, D. Haak, and P. Martin. 2008. Impacts of climate warming on terrestrial ectotherms across latitude. Proceedings of the National Academy of Sciences USA 105:6668-6672.

Didham, R., J. Tylianakis, N. Gemmell, T. Rand, and R. Ewers. 2007. Interactive effects of habitat loss and species invasion on native species decline. Trends in Ecology \& Evolution 22:489-496.

Epstein, P. R. 2001. Climate change and emerging infectious diseases. Microbes and Infection 3:747-754.

Fa, J., C. Peres, and J. Meeuwig. 2002. Bushmeat exploitation in tropical forests: an intercontinental comparison. Conservation Biology 16:232-237.

Feeley, K., S. J. Wright, M. Supardi, A. Kassim, and S. Davies. 2007. Decelerating growth in tropical forest trees. Ecology Letters 10:461469.

Fjeldså, J., and J. Lovett. 1997. Geographical patterns of old and young species in African forest biota: the significance of specific montane areas as evolutionary centres. Biodiversity and Conservation 6:325346. 
Gascon, C., G. Williamson, and G. Fonseca. 2000. Receding edges and vanishing reserves. Science 288:1356-1358.

Gerber, L., H. McCallum, K. Lafferty, J. Sabo, and A. Dobson. 2005. Exposing extinction risk analysis to pathogens: is disease just another form of density dependence? Ecological Applications 15:14021414 .

Geist, H., and E. Lambin. 2001. What drives tropical deforestation? LUCC report series 4. University of Louvain, Leuven, Belgium.

Griffiths, M., and C. van Shaik. 1993. The impact of human traffic on the abundance and activity periods of Sumatran rain forest wildlife. Conservation Biology 3:623-626.

Harvell, C., C. Mitchell, J. Ward, S. Altizer, A. Dobson, R. Ostfield, and M. Samuel. 2002. Climate warming and disease risk for terrestrial and marine biota. Science 296:2158-2162.

Hilbert, D., M. Bradford, T. Parker, and D. Westcott. 2004. Golden bowerbird (Prionodura newtoniana) habitat in past, present and future climates: predicted extinction of a vertebrate in tropical highlands due to global warming. Biological Conservation 116:367377.

Hobbs, R. 2001. Synergisms among habitat fragmentation, livestock grazing, and biotic invasions in southwestern Australia. Conservation Biology 15:1522-1528.

Holdsworth, A., and C. Uhl. 1997. Fire in the eastern Amazonian logged rain forest and the potential for fire reduction. Ecological Applications 7:713-725.

Howard, J. 2002. Environmental 'nasty surprise' as a window on precautionary thinking. Technology and Society Magazine 21:19-22.

Humphries, S., and P. Stanton. 1992. Environmental weeds of the Wet Tropics of Queensland World Heritage Area. Wet Tropics Management Authority, Cairns, Queensland.

Janzen, D. H. 1967. Why mountain passes are higher in the tropics. The American Naturalist 101:233-249.

Jipp, P., D. Nepstad, and K. Cassell. 1998. Deep soil moisture storage and transpiration in forests and pastures of seasonally-dry Amazonia. Climate Change 39:395-412.

Johns, A. G. 1997. Timber production and biodiversity conservation in tropical rain forests. Cambridge University Press, Cambridge, United Kingdom.

Kanowski, J. 2001. Effects of elevated $\mathrm{CO}_{2}$ on the foliar chemistry of seedlings of two rainforest trees from north-east Australia: implications for folivorous marsupials. Austral Ecology 26:165-172.

Kapos, V. 1989. Effects of isolation on the water status of forest patches in the Brazilian Amazon. Journal of Tropical Ecology 5:173-185.

Kiesecker, J. 2002. Synergism between trematode infection and pesticide exposure: a link to amphibian limb deformities in nature? Proceedings of the National Academy of Sciences USA 99:99009904.

Kiesecker, J., and A. Blaustein. 1995. Synergism between UV-B radiation and a pathogen magnifies amphibian embryo mortality in nature. Proceedings of the National Academy of Sciences USA 92:1104911052.

Koren, I., Y. Kaufman, L. Remer, and J. Martins. 2004. Measurement of the effect of Amazon smoke on inhibition of cloud formation. Science 303:1342-1345.

Lafferty, K., and R. Holt. 2003. How should environmental stress affect the population dynamics of disease? Ecology Letters 6:654-664.

Laporte, N., J. Stabach, R. Grosch, T. Lin, and S. Goetz. 2007. Expansion of industrial logging in central Africa. Science 316:1451.

Laurance, W. F. 2001. Tropical logging and human invasions. Conservation Biology 15:4-5.

Laurance, W. F. 2004. Forest-climate interactions in fragmented tropical landscapes. Philosophical Transactions of the Royal Society B 359:345-352.

Laurance, W. F. 2008a. Global warming and amphibian declines in eastern Australia. Austral Ecology 33:1-9.

Laurance, W. F. 2008b. Expect the unexpected. New Scientist 12 April: 17.
Laurance, W. F. 2009. Move over, polar bear. New Scientist 10 November: 14 .

Laurance, W. F., and M. Cochrane. 2001. Synergistic effects in fragmented landscapes. Conservation Biology 15:1488-1489.

Laurance, W. F., M. Cochrane, S. Bergen, P. M. Fearnside, P. Delamonica, C. Barber, S. D'Angelo, and T. Fernandes. 2001. The future of the Brazilian Amazon. Science 291:438-439.

Laurance, W. F., J. M. Fay, R. Parnell, A. Formia, and M. Lee. 2008. Does rainforest logging threaten marine turtles? Oryx 42:246-251.

Laurance, W. F., L. Ferreira, J. Rankin-de Merona, and S. Laurance. 1998. Rain forest fragmentation and the dynamics of Amazonian tree communities. Ecology 79:2032-2040.

Laurance, W. F., and G. Harrington. 1997. Ecological associations of feral pig foraging sites in tropical Queensland. Wildlife Research 24:579-590.

Laurance, W. F., K. R. McDonald, and R. Speare. 1996. Epidemic disease and the catastrophic decline of Australian rain forest frogs. Conservation Biology 10:406-413.

Laurance, W. F., H. Nascimento, S. Laurance, A. Andrade, K. Harms, R. Ewers, K. Harms, R. Luizão, and J. Ribeiro. 2007. Habitat fragmentation, variable edge effects, and the landscape-divergence hypothesis. Public Library of Science ONE DOI:10.1371/journal.pone.0001017.

Laurance, W. F., et al. 2004. Pervasive alteration of tree communities in undisturbed Amazonian forests. Nature 428: 171-175.

Laurance, W. F., and G. Williamson. 2001. Positive feedbacks among forest fragmentation, drought, and climate change in the Amazon. Conservation Biology 15:1529-1535.

Lewis, S., Y. Malhi, and O. Phillips. 2004. Fingerprinting agents of global change in tropical forests. Philosophical Transactions of the Royal Society B 359:437-462.

Malcolm, J., C. Liu, R. Nielson, L. Hansen, and L. Hannah. 2006. Global warming and extinctions of endemic species from biodiversity hotspots. Conservation Biology 20:538-548.

Meggers, B. 1994. Archeological evidence for the impact of mega-Niño events on Amazonian forests during the past two millennia. Climatic Change 28:321-338.

Mikalski, F., and C. Peres. 2005. Anthropogenic determinants of primate and carnivore local extinctions in a fragmented forest landscape of southern Amazonia. Biological Conservation 124:383-396.

Myers, N. 1986. The extinction spasm impending: synergisms at work. Conservation Biology 1:14-21.

Myers, N. 1996. Two key challenges for biodiversity: discontinuities and synergisms. Biodiversity and Conservation 5:1025-1034.

Nascimento, H., and W. F. Laurance. 2004. Biomass dynamics in Amazonian forest fragments. Ecological Applications 14:S127-S138.

Navas, C. A. 1997. Thermal extremes at high elevations in the Andes: physiological ecology of frogs. Journal of Thermal Biology 22:467477.

Negri, A., R. Adler, L. Xu, and J. Surratt. 2004. The impact of Amazonian deforestation on dry season rainfall. Journal of Climate 17:13061319.

Nepstad, D., et al. 1999. Large-scale impoverishment of Amazonian forests by logging and fire. Nature 398:505-508.

Nobre, C., P. Sellers, and J. Shukla. 1991. Amazonian deforestation and regional climate change. Journal of Climate 4:411-413.

Noss, A. 1998. The impacts of cable snare hunting on wildlife populations in the forests of the Central African Republic. Conservation Biology 12:390-398.

O'Dowd, D., P. Green, and P. Lake. 2003. Invasional meltdown on an oceanic island. Ecology Letters 6:812-817.

Peres, C. 2001. Synergistic effects of subsistence hunting and habitat fragmentation on Amazonian forest vertebrates. Conservation Biology 15:1490-1505.

Phillips, O., et al. 1998. Changes in the carbon balance of tropical forests: evidence from long-term plots. Science 282:439-442.

Pimm, S. 1996. Lessons from a kill. Biodiversity and Conservation 5:1059-1067. 
Porter, W., J. Jaeger, and I. Carlson. 1999. Endocrine, immune, and behavioural effects of aldicarb (carbamate), atrazine (triazine) and nitrate (fertilizer) mixtures at groundwater concentrations. Toxicology and Industrial Health 15:133-150.

Pounds, J. A., et al. 2006. Widespread amphibian extinctions from epidemic disease driven by global warming. Nature 439:161-167.

Rahbek, C. 1997. The relationship among area, elevation, and regional species richness in Neotropical birds. The American Naturalist 149:875-902.

Reed, S., and A. Merenlender. 2008. Quiet, nonconsumptive recreation reduces protected area effectiveness. Conservation Letters 1:146154.

Robinson, J., and E. Bennett. 2000. Hunting for sustainability in tropical forests. Columbia University Press, New York.

Robinson, J., K. Redford, and E. Bennett. 1999. Wildlife harvest in logged tropical forests. Science 284: 595-596.

Rosenfeld, D. 1999. TRMM observed first direct evidence of smoke from forest fires inhibiting rainfall. Geophysical Research Letters 26:3105-3108.

Sala, O., et al. 2000. Global biodiversity scenarios for the year 2100 . Science 287:1770-1774.

Salafsky, N., et al. 2008. A standard lexicon for biodiversity conservation: unified classifications of threats and actions. Conservation Biology 22:897-911.

Sanford, R., J. Saldarriaga, K. Clark, C. Uhl, and R. Herrera. 1985. Amazon rain-forest fires. Science 227:53-55.

Schipper, J., et al. 2008. The status of the world's land and marine mammals: diversity, threat, and knowledge. Science 322:225-230.

Shearman, P., J. Bryan, J. Ash, P. Hunnam, B. Mackey, and B. Lokes. 2008. The state of the forests of Papua New Guinea. University of Papua New Guinea, Port Moresby.

Siegert, F., G. Ruecker, A. Hinrichs, and A. Hoffmann. 2001. Increased damage from fires in logged forests during droughts caused by El Niño. Nature 414:437-440.

Simberloff, D., and B. Von Holle. 1999. Positive interactions of nonindigenous species: invasional meltdown? Biological Invasions 1:21-32.

Smith, K. F., D. Sax, and K. Lafferty. 2006. Evidence for the role of infectious disease in species extinction and endangerment. Conservation Biology 20:1349-1357.

Taylor, M., S. Klaine, F. Carvalho, D. Barcelo, and J. Everaarts. 2003. Pesticide residues in coastal tropical ecosystems: distribution, fate and effects. Taylor \& Francis, New York.

Terborgh, J., et al. 2001 Ecological meltdown in predator-free forest fragments. Science 294:1923-1926.
Thomas, C. D., et al. 2004. Extinction risk from climate change. Nature 427:145-148.

Traill, L., C. Bradshaw, H. Field, and B. Brook. 2009. Climate change enhances the potential impact of infectious disease and hunting on tropical waterfowl. Biotropica. 41: DOI:10.1111/j.17447429.2009.00508.x.

Turton, S., editor. 2008. Ecological impacts of tropical cyclones on Australian terrestrial vegetation: insights from Cyclones Larry and Monica. Austral Ecology 33:365-584.

Vera, C., G. Silvestri, B. Liebmann, and P. González. 2006. Climate change scenarios for seasonal precipitation in South America from IPCC-AR4 models. Geophysical Research Letters 33: DOI:10.1029/2006GL025759.

Vié, J.-C., C. Hilton-Taylor, C. Pollock, J. Ragle, J. Smart, S. N. Stuart, and R. Tong. 2008. The IUCN Red List: a key conservation tool. International Union for Conservation of Nature, Gland, Switzerland.

Walsh, K., and B. Ryan. 2000. Tropical cyclone intensity increases near Australia as a result of climate change. Journal of Climate 13:30293036.

Walsh, P., et al. 2003. Catastrophic ape decline in western equatorial Africa. Science 422:611-614.

Weathers, K., M. Cadenasso, and S. Pickett. 2001. Forest edges as nutrient and pollution concentrators: potential synergisms between fragmentation, forest canopies, and the atmosphere. Conservation Biology 15:1506-1514.

Wilkie, D., E. Shaw, F. Rotberg, G. Morelli, and P. Auzel. 2000. Roads, development, and conservation in the Congo Basin. Conservation Biology 14:1614-1622.

Williams, S., E. Bolitho, and S. Fox. 2003. Climate change in Australian tropical rainforests: an impending environmental catastrophe. Proceedings of the Royal Society of London B 270:18871892.

Williams, J., S. Jackson, and J. Kutzbach. 2007. Projected distributions of novel and disappearing climates by 2100 AD. Proceedings of the National Academy of Sciences USA 104:5738-5742.

Woodroffe, R., and J. Ginsberg. 1998. Edge effects and the extinction of populations inside protected areas. Science 280:2126-2128.

Wright, S. J. 2005. Tropical forests in a changing environment. Trends in Ecology \& Evolution 20:553-560.

Wright, S. J., and H. C. Muller-Landau. 2006. The uncertain future of tropical forest species. Biotropica 38:443-445

Zala, S., and D. Penn. 2004. Abnormal behaviors induced by chemical pollution: a review of the evidence and new challenges. Animal Behaviour 68:649-664.

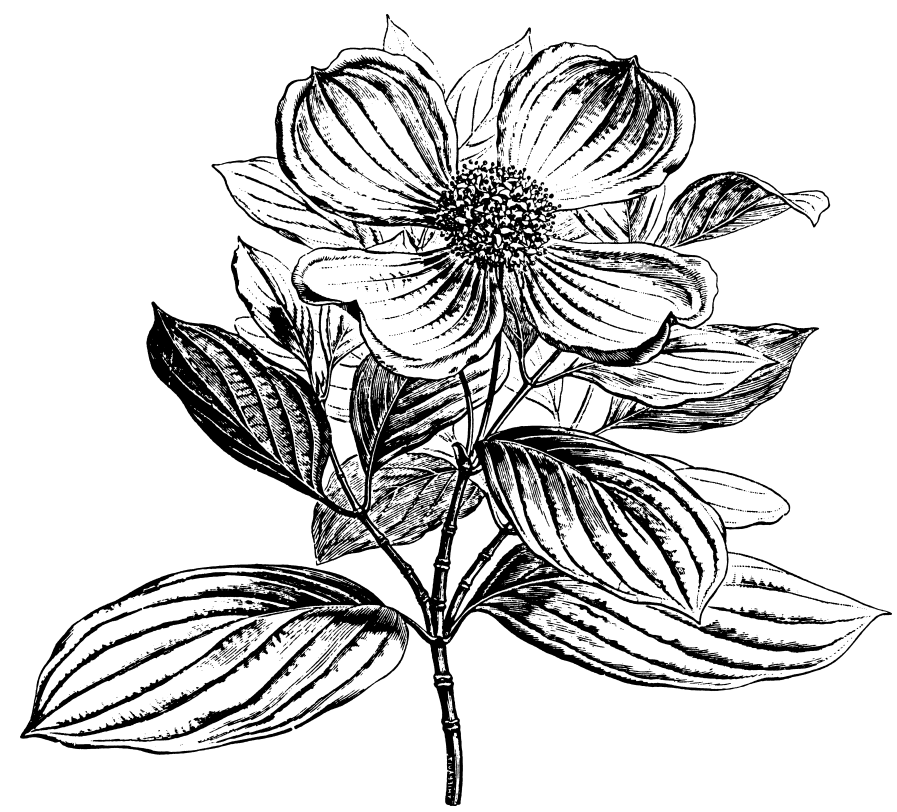

